\title{
Pea Tissue Necrosis Induced by Cucumber mosaic virus Alone or Together with Watermelon mosaic virus
}

F. Fukumoto, National Agricultural Research Center, Department of Rice Research, Joetu, Inada, Niigata 943-0193 Japan; Y. Masuda, Wakayama Research Center of Agriculture, Forestry and Fisheries, Agricultural Experiment Station, Takao, Kishigawa, Naga, Wakayama 640-0423 Japan; and K. Hanada, National Agricultural Research Center for Kyushu Okinawa Region, Nishigoshi, Kikuchi, Kumamoto 861-1192 Japan

\begin{abstract}
Fukumoto, F., Masuda, Y., and Hanada, K. 2003. Pea tissue necrosis induced by Cucumber mosaic virus alone or together with Watermelon mosaic virus. Plant Dis 87:324-328.

Necrotic diseases of the stems, petioles, and leaves of pea plants (Pisum sativum L.), leading to wilting and death, occur in the Wakayama and Mie Prefectures of Japan. Based on host range, symptomatology, electron microscopy, and serological relationships, Watermelon mosaic virus (WMV) and three Cucumber mosaic virus (CMV) isolates (PE2, PE3A, and PB1) were isolated from diseased plants in the Wakayama Prefecture. In the Mie Prefecture, CMV (PEAN) also was isolated from pea plants with similar symptoms. Single infection with CMV (PB1 or PEAN) caused stem necrosis and eventual death of pea plants. Similar symptoms developed after double infection with WMV and PE2 or PE3A, whereas single infection with PE2 and PE3A induced symptomless infection in pea plants. We concluded either CMV alone or synergistic effects of mixed infection with CMV and WMV induced pea plant stem necrosis.
\end{abstract}

Inouye et al. (6) and Matsumoto et al. (8) first reported stem necrosis diseases of pea plants (Pisum sativum L.) in Japan. In both studies, Cucumber mosaic virus (CMV) was isolated from the pea plants tested. As a result, CMV infection alone was considered to cause stem necrosis diseases in pea plants. Pea stem necrosis virus (PSNV) also has been noted as the causal agent of pea necrotic disease with symptoms such as browning, necrotic streaking in stems and petioles, and vein necrosis and yellowing in leaflets (9).

Necrotic diseases in the stems, petioles, and leaves of pea plants, followed by wilting and finally death, occurred in the Wakayama and Mie Prefectures of Japan in 1992 and 1994, respectively. We isolated Watermelon mosaic virus (WMV) and CMV from these pea plants. After locallesion isolation of the viruses, infection with either of two CMV isolates (PB1 or PEAN) induced stem necrosis and eventual

Corresponding author: F. Fukumoto E-mail: ffuku@affrc.go.jp

Current address of F. Fukumoto: National Agricultural Research Center for Hokkaido Region, Plant Virology Lab., Hitsujigaoka, Toyohira, Sapporo 062-8555 Japan

Current address of K. Hanada: National Institute of Agrobiological Sciences, Kannondai, Tsukuba, Ibaraki 305-8602 Japan

Accepted for publication 28 October 2002.

Publication no. D-2003-0127-01R

(C) 2003 The American Phytopathological Society death of pea plants. Similar symptoms developed with double infections of WMV and the PE2 or PE3A isolate of CMV. However, single infection with either of these CMVs produced no obvious symptoms on pea plants.

In this study, we describe the properties of the WMV and CMV isolates obtained from pea plants showing severe necrosis and compare the severity of necrotic symptoms in pea plants with single or double infections of the viruses isolated.

\section{MATERIALS AND METHODS}

Source plants and isolation of viruses. The viruses used were obtained from a naturally infected pea plant (P. sativum L., cv. Misasa) at Iinamicho in the Wakayama Prefecture, Japan, in 1992. The plant was expressing symptoms of necrosis on the stem, petiole, leaf, and pod followed by wilting and finally death (Fig. 1). The virus was also isolated from a pea plant (cv. 30day kinusaya) with stem and bud necrosis at Ano-cho in the Mie Prefecture, Japan, in 1994 (Fig. 1). Two distinct viruses (WMVPEW and CMV isolates of PE2, PE3A, and PB1) were isolated from diseased pea plants in the Wakayama Prefecture, and one virus (CMV-PEAN) was isolated in the Mie Prefecture. Upon development of symptoms on more than 10 test plants and observation of virus particles with electron microscope, filamentous and spherical virus particles were observed in plants inoculated from the original diseased pea plants with necrotic symptoms in the Wakayama Prefecture in 1992. The filamentous virus, isolated by subculturing to ses- ame plants, was propagated in pumpkin after three successive single-lesion transfers on Chenopodium quinoa. The spherical virus was propagated in Nicotiana tabacum or $N$. glutinosa after three or four single-lesion transfers using $C$. quinoa.

Host range and symptoms. Host ranges of the viruses isolated were determined by mechanical inoculation using crude extracts from leaves of infected plants homogenized in $0.1 \mathrm{M}$ potassium phosphate buffer (PB), $\mathrm{pH} 7.0$, containing $0.1 \% 2$ mercaptoethanol and $10 \mathrm{mM}$ sodium ethylenediamine tetraacetic acid. The presence of the virus in inoculated and uninoculated upper leaves of the test plants was assayed by back-inoculation to $C$. quinoa or $C$. amaranticolor.

Aphid and seed transmission tests. Aphids (Myzus persicae) reared on healthy turnip plants were starved for 2 to $3 \mathrm{~h}$ in glass beakers, then fed on plants infected with WMV or CMV for 1 to $5 \mathrm{~min}$ to acquire the virus. Ten aphids were transferred to healthy plants for inoculation access of 3 to $4 \mathrm{~h}$. Seed transmission tests were carried out as follows: pea seedlings (cv. 30-day kinusaya) were inoculated with a CMV isolate 10 days after sowing and, seeds from the CMV-infected pea plants were grown in an insect-free greenhouse. To assay for virus infection, leaf extracts of the 10-day-old germinated seedling were inoculated on $C$. quinoa to confirm the presence of the virus.

Purification and serological tests. Viruses were purified as follows: CMV isolates were propagated in tobacco plants (cv. Xanthi nc) and purified according to the method of Tochihara (17), with minor modifications such as the use of borate buffer instead of phosphate buffer. Purified CMV samples supplemented with $1 \%$ sucrose as a protectant for freezing were preserved at $-80^{\circ} \mathrm{C}$ until use. Double diffusion tests were performed on CMVs in $1 \%$ agarose in $0.05 \mathrm{M} \mathrm{Na}-\mathrm{PB}, \mathrm{pH} 7.6$, containing $0.85 \% \mathrm{NaCl}$ and $0.1 \% \mathrm{NaN}_{3}(4)$. Simplified double diffusion tests using crude extracts were also done for serological diagnosis of WMV, Zucchini yellow mosaic virus (ZYMV), Clover yellow vein virus (CYVV), and Bean yellow mosaic virus (BYMV).

Electron microscopy. Leaf dip preparations were stained with $2 \%$ uranyl acetate 
without $\mathrm{pH}$ adjustment and examined with a Hitachi H-600 electron microscope.

Synergism experiments of double infection with WMV and CMV. To evaluate the synergistic effects of double infection with WMV and CMV, the mortality rate, appearance, and severity of symptoms such as stem necrosis were compared with those resulting from single infection with WMV or CMV. Crude extracts from infected snap beans and pumpkins were used as inocula for WMV after being diluted 20 to 30 times with the same buffer used for host range determination because of suppression of virus infection by host components. For CMV, purified virus samples were used. The inocula, mixed crude extracts of WMV and purified CMV, were applied to several expanded leaves of pea seedlings (cv. 30-day kinusaya) either simultaneously 10 days after germination or sequentially by applying WMV followed by CMV 1 week later or vice versa. Symptoms were observed for 40 days post inoculation.

\section{RESULTS}

Identification of WMV and CMV. After three successive local-lesion isolations, the crude extracts of pumpkin leaves infected with a filamentous virus were inoculated to test plants. Of 37 plant species in nine families tested, 21 species in seven families were susceptible to the virus with filamentous particles (Table 1). Pea plants expressed mosaic symptoms similar to those reported previously for WMV (5). Almost all of the plant species tested belonging to the Leguminosae and Cucurbitaceae families developed systemic mosaic symptoms. Myzus persicae fed on cucumber infected with the filamentous virus and transmitted the virus to 6 of 10 cucumber and 3 of 10 pea plants, and the plants eventually developed mosaic symptoms. Crude leaf extracts of plants infected with the unknown virus isolate reacted to WMV antiserum and formed a single band in agar gel, but did not react with antisera to ZYMV, CYVV, or BYMV (data not shown). It is noted that serological relationships exist between WMV and ZYMV and CYVV and BYMV (14). It is noted that WMV systemically infects $N$. benthamiana and bean plants, while ZYMV infects these plants only locally (14). Papaya ringspot virus does not infect $N$. benthamiana (13). Based on these results and information, the filamentous virus in this study was identified as WMV and hereafter named the PEW isolate.

The PE2, PE3A, PB1, and PEAN isolates of CMV were isolated from diseased plants through inoculation of successive local-lesion transfers on $C$. quinoa. The host range of these isolates was determined by inoculation on a wide range of plant species (Table 1). Of 41 plant species in 11 families tested, 34 species from nine families were susceptible to PE2. Similarly,
PE3A, PB1, and PEAN infected 31, 32, and 29 species, respectively, in nine families with variable reactions to some. All of the isolates had wide host ranges. However, the host ranges and reactions of these isolates differed to some extent in plants of the Leguminosae and Cucurbitaceae families (Table 1). These isolates were transmitted efficiently by $M$. persicae from tobacco to tobacco (data not shown) and pea plants. The rates of aphid transmission of PE2, PE3A, PB1, and PEAN to pea plants were 10 of 22,17 of 26,11 of 14 , and 5 of 15 , respectively. Inoculation of pea plants with PE2 and PE3A resulted in symptomless infection, but inoculations with PB1 and PEAN induced stem necrosis, wilting, and death to 9 of 11 and 3 of 5 plants, respectively (Fig. 2A). Small spherical virus particles (approximate diameter of $30 \mathrm{~nm}$ ) were observed in crude saps of pumpkin leaves infected with the PE2 isolate. The PE2 and PB1 isolates were not transmitted through 462 and 339 seed, respectively, collected from diseased pea plants in a greenhouse. In agar gel double-diffusion tests, isolates of PE2 and PE3A reacted positively to antiserum to CMV-Y belonging to subgroup I (19), forming single fused bands with CMV-Y, whereas PB1 and PEAN formed spurs (Fig. 3).

Consequently, PE2 and PE3A were classified in subgroup I of CMV based on serological reactions. PB1 and PEAN were different from subgroup I on serological reactions, and induced necrotic ring symptoms on inoculated leaves of tobacco plant (cv. Xanthi nc), which is characteristic of CMV isolates belonging to subgroup II of CMV (21). Therefore, these isolates were classified into subgroup II of CMV. PE2 and PE3A induced symptomless infection in pea plants. In contrast, vein necrosis, stem necrosis, and death of pea plants were induced by infection of PB1 or PEAN (Table 1; Fig. $2 \mathrm{~A}$ and B). Thus, pea plants showed distinct symptoms after infection with CMV of subgroup I and II.

Appearance of necrotic symptoms in pea plants with single infections of CMV isolates. We compared symptoms produced by mechanical inoculation with isolates of CMV obtained from pea plants that had necrotic symptoms (Table 1). PE2 did not induce symptoms in systemically infected pea plants even when the virus concentration in the inoculum increased from 1.5 $\mu \mathrm{g} / \mathrm{ml}$ to $50 \mu \mathrm{g} / \mathrm{ml}$. With single infection, PB1 and PEAN induced systemic necrosis and subsequent death of inoculated pea plants when the CMV concentration in the inoculum was high (Table 2; Fig. 2B). In general, the symptoms observed were more severe at higher concentrations of inoculum. With PEAN, the mortality rate of plants became higher as the virus concentration in the inoculum increased. In the

Table 1. Host range and symptoms of Watermelon mosaic virus (WMV) and Cucumber mosaic virus (CMV) isolated from pea plants

\begin{tabular}{|c|c|c|c|c|c|}
\hline \multirow[b]{2}{*}{ Plants (cultivar) } & \multirow{2}{*}{$\begin{array}{l}\text { WMV } \\
\text { PEW }\end{array}$} & \multicolumn{4}{|c|}{ CMV } \\
\hline & & PE2 & PE3A & PB1 & PEAN \\
\hline Pisum sativum (30-day kinusaya) & $\mathrm{M}^{\mathrm{a}}$ & + & + & Sn, D & Sn, D \\
\hline \multicolumn{6}{|l|}{ Glycine $\max$} \\
\hline (Tsurunoko) & $+/-$ & - & - & + & - \\
\hline (Okuharawase) & - & $+/-$ & $+/-$ & $(+) /-$ & - \\
\hline Vicia faba (Issun) & M & Rs,M & $\mathrm{N} / \mathrm{N}, \mathrm{Rs}$ & $\mathrm{m}$ & Ns/- \\
\hline Vigna sesquipedalis (Kurodane-sanjaku) & - & $\mathrm{N}, \mathrm{Cs} / \mathrm{M}$ & + & M & Ns/- \\
\hline \multicolumn{6}{|l|}{ Phaseolus vulgaris } \\
\hline (Honkintoki) & M & $\mathrm{Ns} / \mathrm{M}$ & $\mathrm{C} / \mathrm{M}, \mathrm{N}$ & $\mathrm{m}$ & Ns/- \\
\hline (Top Crop) & - & $+/(+)$ & $+/-$ & Ns/- & Ns/- \\
\hline (Yamashirokurosando) & $\mathrm{Cs} / \mathrm{M}$ & $\mathrm{N} / \mathrm{N}$ & + & Ns/M & - \\
\hline Vigna angularis & - & $+/-$ & - & $(\mathrm{M})$ & M \\
\hline Nicotiana benthamiana & + & Ym & M & + & + \\
\hline N. glutinosa & - & Ym & $\mathrm{m}$ & M & M \\
\hline N. clevelandii & $+/-$ & Ym & + & M & M \\
\hline N. rustica & - & Ym & $\mathrm{m}$ & M & M \\
\hline \multicolumn{6}{|l|}{ N. tabacum } \\
\hline (Xanthi nc) & - & Ym & + & $\mathrm{Nr} / \mathrm{M}$ & $\mathrm{Nr} / \mathrm{M}$ \\
\hline (Bright Yellow) & NT & Ym & + & NT & M \\
\hline Lycopersicon esculentum (Fukujyu No.2) & - & + & $\mathrm{m}$ & $+/(+)$ & $+1-$ \\
\hline Chenopodium amaranticolor & s/- & $\mathrm{Cs} /-$ & $\mathrm{Cs} /-$ & $\mathrm{Cs} /-$ & $\mathrm{Cs} /-$ \\
\hline C. quinoa & s/- & $\mathrm{Ns} / \mathrm{Cs}, \mathrm{Ml}$ & Ns/- & Ns/- & Ns/- \\
\hline Cucumis sativus (Sagamihanjiro) & M & $+/-$ & $+/-$ & M & M \\
\hline Cucurbita реро (Kinshi) & M,Ml & $+/-$ & $\mathrm{M}$ & $\mathrm{Cs} / \mathrm{M}$ & $\mathrm{Cs} /-$ \\
\hline Cucurbita maxima (Tokyo) & M,Ml & M & M & M & $\mathrm{Cs} /-$ \\
\hline Cucurbita moschata (Shirogikuza) & M & $+/-$ & $+/-$ & $\mathrm{Cs} / \mathrm{Vy}$ & $\mathrm{Cs} /-$ \\
\hline Cucumis melo (reticulatus group) & M & M & M & M & M \\
\hline Luffa cylindrica & $\mathrm{Cs}$ & $\mathrm{Cs} / \mathrm{M}$ & M & - & - \\
\hline Sesamum indicum (white) & $\mathrm{M}, \mathrm{N}$ & Ns/- & Ns/- & Ns/- & N/Sn,D \\
\hline
\end{tabular}

a Abbrevation for symptoms: $\mathrm{C}=$ chlorosis; $\mathrm{Cs}=$ chlorotic spot; $\mathrm{D}=$ death of plants; $\mathrm{M}=$ mosaic; $\mathrm{Ml}$ = malformation $; \mathrm{m}=$ mild mosaic $; \mathrm{N}=$ necrosis $; \mathrm{Nr}=$ necrotic ringsopt $; \mathrm{Ns}=$ necrotic spot; $\mathrm{Rs}=$ ringspot; $\mathrm{Sn}=$ stem necrosis; $\mathrm{Vy}=$ vein yellowing; $\mathrm{Ym}=$ yellow mosaic $;+=$ symptomless infection; $($ ) = rarely infected; $-=$ not infected; and NT $=$ not tested. 
case of PB1, rates of plants inducing stem necrosis and death were variable in Tables 2,3 , and 4 showing $35 \%$ (19 of 55), $22 \%$ (11 of 49), and 7\% (4 of 54) in the sum of the inoculated plants regardless of the concentration of virus inoculum, respectively. Rates in PEAN were $82 \%$ (45 of 55), 36\% (21 of 59), and 65\% (17 of 26), respectively. These results indicated that single infection of pea plants with PB1 or PEAN induced necrotic symptoms such as stem necrosis, bud necrosis, and death after wilting (hereafter called the necrotic syndrome); and PEAN induced more severe necrotic symptoms and increase of plant mortality than PB1.
We used back-inoculation to $C$. amaranticolor to test for the presence of the virus in the upper or newly sprouted leaves of pea plants showing stem necrosis with occasional bud necrosis. We detected virus infection in the new buds of only 1 of 16 plants with necrotic symptoms induced by infection with PB1 isolate. Similar tendencies were also observed clearly with the PEAN isolate. None of the preparations of upper leaves from 15 plants inoculated with the PEAN isolate that showed stem necrosis contained the virus. Therefore, movement of PB1 and PEAN to upper leaves might be prevented by the development of necrotic, hypersensitive reactions.
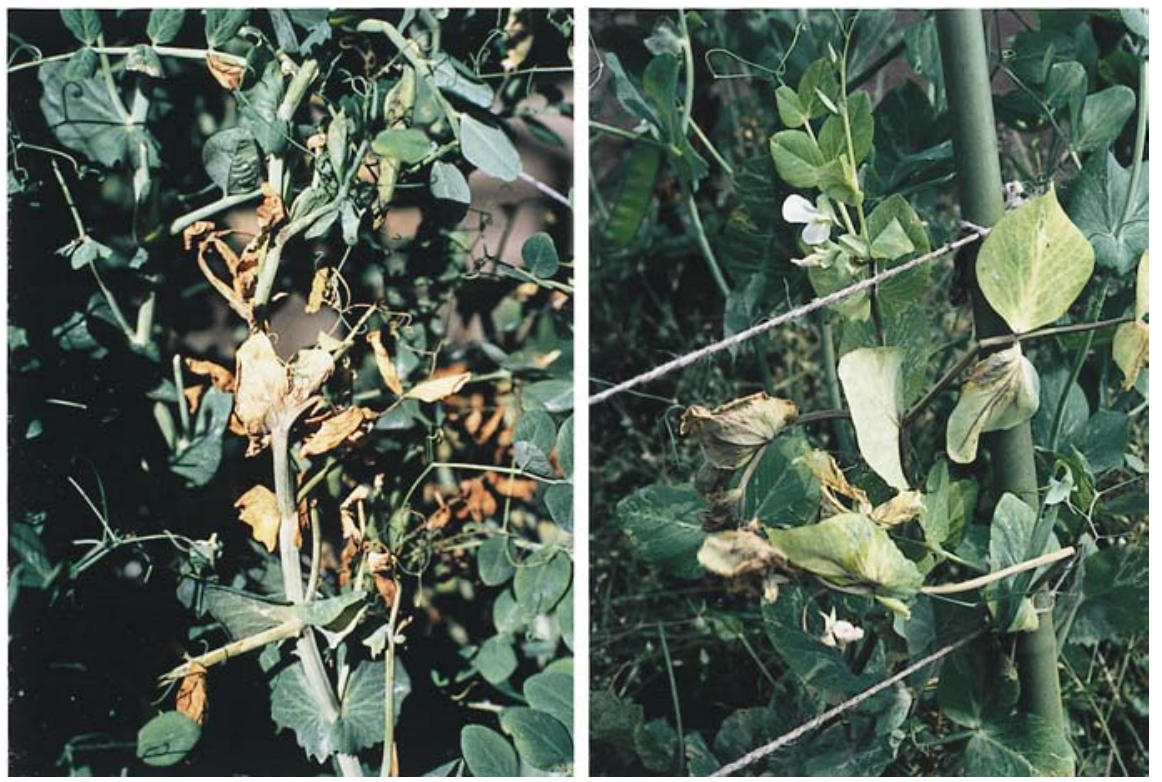

Fig. 1. Necrotic diseases naturally occurring in pea plants in the Wakayama (left) and Mie (right) Prefectures, Japan. Cultivars are Usui and 30-day kinusaya, respectively.
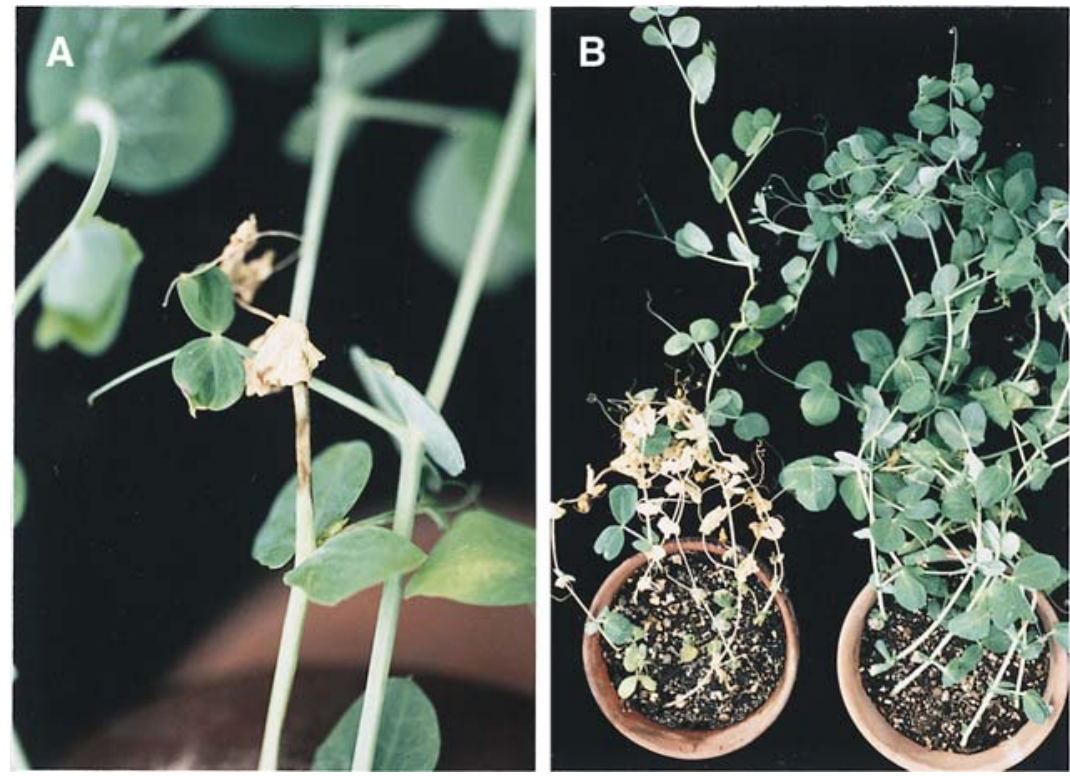

Fig. 2. A, Primary symptoms of stem necrosis on pea plants (cv. 30-day kinusaya) induced by aphid transmission of Cucumber mosaic virus (CMV) (PB1 isolate), which eventually cause death. B, Symptoms of CMV (PEAN) isolate on pea plants (left) (cv. 30-day kinusaya) mechanically inoculated with $50 \mu \mathrm{g} / \mathrm{ml}$ of purified preparations; (right) healthy pea plants.
However, pea plants showed weaker response from PB1 than PEAN. PB1 infected pea plants may be systemically infected while showing slight necrotic symptoms; in contrast PEAN does not infect systemically at all (Table 2).

Appearance and enhancement of necrotic symptoms in pea plants with double infections of CMV and WMV. We investigated the appearance and enhancement of necrotic symptoms in double infections with CMV and WMV. In pea plants simultaneously inoculated with PE2-CMV and WMV, the necrotic syndrome developed at all concentrations of CMV used $(5,15$, and $50 \mu \mathrm{g} / \mathrm{ml}$ ) (Table $3)$. In contrast, single infection with PE2 did not produce obvious symptoms ( $\mathrm{Ta}-$ bles 1 and 2), and infection with WMV

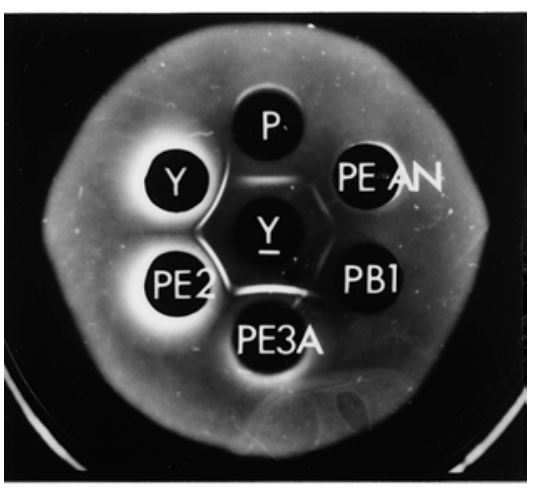

Fig. 3. Immunodiffusion test with Cucumber mosaic virus (CMV) isolates. Center well contains antiserum to CMV-Y (subgroup I). Each outer well contains purified viruses of $(\mathrm{Y})$ CMV-Y, (P) CMV-P (subgroup II), and each isolate of PE2, PE3A, PB1, and PEAN isolated in this study.

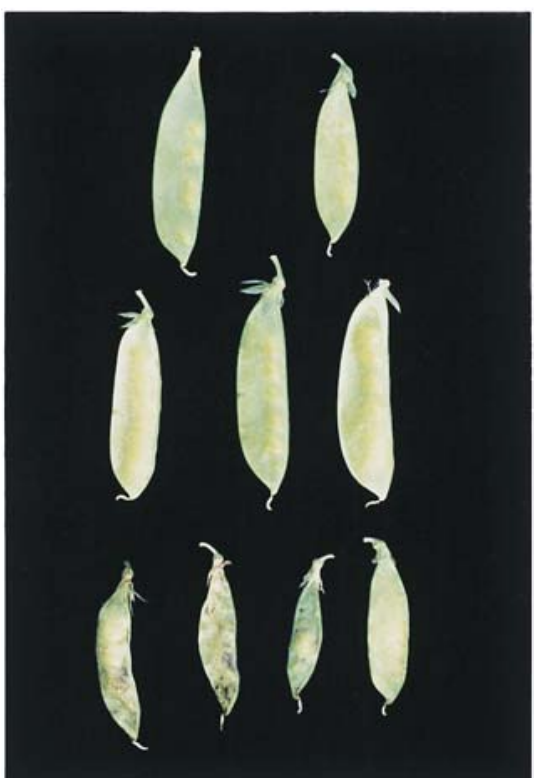

Fig. 4. Symptoms on pods of pea plants inoculated with watermelon mosaic virus (WMV) and PE2 isolate of Cucumber mosaic virus $(\mathrm{CMV})$. Upper $=\mathrm{WMV}$ alone; middle $=\mathrm{CMV}$ PE2 alone; and lower $=\mathrm{WMV}$ plus CMV-PE2. 
alone caused mosaic symptoms only. When PE2 was inoculated 1 week after WMV, the necrotic syndrome was also induced (Table 4). When PE2 at three different concentrations was inoculated 1 week before WMV, a similar necrotic syndrome was induced in pea plants at a nearly identical rate of $79 \%$ (22 of 28) (data not shown).

To determine the synergistic effect of WMV together with PB1 or PEAN, we inoculated the viruses on pea plants either simultaneously or 1 week before or after WMV inoculation. In the case of PB1, the rates of occurrence of stem necrosis and death of plants were greater with double than single infection, resulting in 23\% (11 of 49 ) to $38 \%$ (19 of 50 ) and $7 \%$ (4 of 54) to $48 \%$ (27 of 56) in Tables 3 and 4, respectively. When PB1 was inoculated under the same conditions with three different virus concentrations described previously 1 week before $\mathrm{WMV}$, the rate of necrosis and death of plants increased $59 \%$ (16 of 27) to $76 \%$ (22 of 29) (data not shown). Similarly, in the case of PEAN, occurrence of the necrotic syndrome by double inoculation with WMV was $36 \%$ (21 of 59) to $54 \%$ (28 of 52) and 65\% (17 of 26) to $85 \%$ (23 of 27) in Tables 3 and 4 , respectively. The rates showed a slight increase with double infections over single infection. Consequently, the synergistic effect of PB1 or PEAN with WMV also occurred, although it was not as pronounced as with that of PE2.
PB1 alone induced symptomless infection in pods of pea plants, but double infection with WMV caused pod necrosis (Fig. 4).

In preliminary tests, single inoculation with PE3A also produced symptomless infection, but all 13 pea plants inoculated with both PE3A and WMV developed stem necrosis and died. These results also confirmed the synergistic effects of PE3A and WMV in pea plants.

\section{DISCUSSION}

In Japan, PSNV is noted as a causal agent of pea necrotic diseases (9). The symptoms and shape of virus particles of PSNV and CMV are similar. However, a chytridiomycete fungus, Olpidium sp. in soil, transmits PSNV, and the host range of

Table 2. Symptoms in pea plants induced by mechanical inoculation with Cucumber mosaic virus isolates

\begin{tabular}{|c|c|c|c|c|c|c|c|c|c|c|}
\hline \multirow{3}{*}{$\begin{array}{l}\text { Concentrations } \\
(\mu \mathrm{g} / \mathrm{ml})\end{array}$} & \multicolumn{2}{|c|}{ PE2 (I) } & \multicolumn{4}{|c|}{ PB1 (II) } & \multicolumn{4}{|c|}{ PEAN (II) } \\
\hline & \multirow{2}{*}{$\begin{array}{c}\text { No } \\
\text { infection }\end{array}$} & \multirow{2}{*}{$\frac{\text { Infection }}{\text { Symptomless }}$} & \multirow{2}{*}{$\begin{array}{c}\text { No } \\
\text { infection }\end{array}$} & \multicolumn{3}{|c|}{ Infection } & \multirow{2}{*}{$\begin{array}{c}\text { No } \\
\text { infection }\end{array}$} & \multicolumn{3}{|c|}{ Infection } \\
\hline & & & & Symptomless & Stem necrosis & Death & & Symptomless & Stem necrosis & Death \\
\hline \multicolumn{11}{|l|}{ Experiment 1} \\
\hline 1.5 & $6^{a}$ & 2 & 8 & 0 & 0 & 0 & 4 & 0 & 3 & 1 \\
\hline 5 & 1 & 7 & 5 & 0 & 3 & 0 & 3 & 0 & 3 & 2 \\
\hline 15 & 0 & 8 & 3 & 1 & 4 & 0 & 2 & 0 & 0 & 6 \\
\hline 50 & $\mathrm{NT}^{\mathrm{b}}$ & NT & 3 & 0 & 3 & 2 & 1 & 0 & 0 & 6 \\
\hline \multicolumn{11}{|l|}{ Experiment 2} \\
\hline 5 & 0 & 7 & 4 & 1 & 1 & 1 & 0 & 0 & 7 & 1 \\
\hline 15 & 0 & 8 & 6 & 1 & 1 & 0 & 0 & 0 & 3 & 5 \\
\hline 50 & 0 & 8 & 3 & 1 & 4 & 0 & 0 & 0 & 1 & 7 \\
\hline
\end{tabular}

a Number of pea plants.

${ }^{\mathrm{b}} \mathrm{NT}=$ not tested.

Table 3. Symptoms in pea plants induced by single and double infection of Cucumber mosaic virus (CMV) isolates together with Watermelon mosaic virus (WMV)

\begin{tabular}{|c|c|c|c|c|c|c|c|c|c|}
\hline \multirow{2}{*}{$\begin{array}{l}\text { CMV concentrations } \\
(\mu \mathrm{g} / \mathrm{ml})\end{array}$} & \multicolumn{3}{|c|}{ PE2 (I) } & \multicolumn{3}{|c|}{ PB1 (II) } & \multicolumn{3}{|c|}{ PEAN (II) } \\
\hline & No necrosis ${ }^{b}$ & Stem necrosis & Death & No necrosis ${ }^{b}$ & Stem necrosis & Death & No necrosis ${ }^{\mathbf{b}}$ & Stem necrosis & Death \\
\hline \multicolumn{10}{|l|}{ Single inoculation } \\
\hline 5 & $18^{\mathrm{c}}$ & 0 & 0 & 12 & 4 & 0 & 18 & 1 & 0 \\
\hline 15 & 18 & 0 & 0 & 15 & 3 & 0 & 14 & 5 & 1 \\
\hline 50 & 9 & 0 & 0 & 11 & 3 & 1 & 6 & 8 & 6 \\
\hline \multicolumn{10}{|l|}{ Double inoculation } \\
\hline 5 & 1 & 13 & 0 & 11 & 4 & 2 & 13 & 5 & 0 \\
\hline 15 & 4 & 10 & 2 & 10 & 6 & 0 & 8 & 8 & 0 \\
\hline 50 & 3 & 6 & 1 & 10 & 5 & 2 & 3 & 8 & 7 \\
\hline
\end{tabular}

${ }^{a}$ Results are the totals from two experiments, except the data on infections with the PE2 isolate at a virus concentration of $50 \mu \mathrm{g} / \mathrm{ml}$.

b WMV alone induces mosaic symptoms. Presence of CMV was not assayed.

c Number of pea plants.

Table 4. Symptoms in pea plants induced by single and double infection of Cucumber mosaic virus (CMV) isolates 1 week after inoculation with Watermelon mosaic virus (WMV)

\begin{tabular}{|c|c|c|c|c|c|c|c|c|c|}
\hline \multirow{2}{*}{$\begin{array}{l}\text { CMV concentrations } \\
(\mu \mathrm{g} / \mathrm{ml})\end{array}$} & \multicolumn{3}{|c|}{ PE2 (I) } & \multicolumn{3}{|c|}{ PB1 (II) } & \multicolumn{3}{|c|}{ PEAN (II) } \\
\hline & No necrosis ${ }^{b}$ & Stem necrosis & Death & No necrosis ${ }^{b}$ & Stem necrosis & Death & No necrosis ${ }^{b}$ & Stem necrosis & Death \\
\hline \multicolumn{10}{|l|}{ Single inoculation } \\
\hline 5 & $10^{c}$ & 0 & 0 & 18 & 0 & 0 & 5 & 4 & 0 \\
\hline 15 & 10 & 0 & 0 & 17 & 2 & 0 & 4 & 4 & 0 \\
\hline 50 & 18 & 0 & 0 & 15 & 1 & 1 & 0 & 3 & 6 \\
\hline \multicolumn{10}{|l|}{ Double inoculation } \\
\hline 5 & 0 & 5 & 3 & 10 & 5 & 2 & 2 & 3 & 3 \\
\hline 15 & 4 & 4 & 1 & 13 & 7 & 0 & 1 & 4 & 5 \\
\hline 50 & 8 & 9 & 0 & 6 & 10 & 3 & 1 & 3 & 5 \\
\hline
\end{tabular}

${ }^{a}$ Results are the totals from two experiments, except the data on infections with the PE2 isolate at a virus concentration of 5 and $15 \mu \mathrm{g} / \mathrm{ml}$, and PEAN isolate.

b WMV alone induces mosaic symptoms. Presence of CMV was not assayed.

c Number of pea plants. 
PSNV is narrow, confined to species of leguminaceae (9). These properties of PSNV are different from those of CMV, which is aphid transmissible and has a much wider host range.

CMV alone has been reported to be the causal agent of similar diseases showing symptoms of stem necrosis, wilting, and finally death of pea plants (6). Matsumoto et al. (8) also isolated CMV from pea plants in the Akita Prefecture with similar necrotic symptoms, and the virus was designated AKP2. AKP2 may belong to subgroup II because these authors observed spur formation between CMV-Y and AKP2 isolates with antiserum to the AKP2 isolate.

PB1 and PEAN isolates of CMV isolated from the Wakayama and Mie Prefectures, respectively, caused necrotic symptoms in pea plants and were classified in subgroup II of CMV based on their serological reactions and biological properties. However, the host ranges and reactions of these two isolates in plants of Leguminosae and Cucurbitaceae families differed to some extent (Table 1), and the PEAN isolate induced more severe necrotic symptoms in pea plants than did PB1. We cannot compare AKP2 with these four isolates because only limited information was available on its host range and symptoms. We are not aware of reports of similar necrotic diseases in pea plants outside of Japan.

Our results indicated that double infection with a CMV isolate (PE2 or PE3A, which infect pea plants symptomlessly) and WMV induced symptoms of stem necrosis, wilting, and eventually death. This is the first report of synergism of two unrelated viruses on pea plants. The synergistic effect was clearer when $\mathrm{CMVs}$ belonging to subgroup I were used. In the case of CMVs belonging to subgroup II, PB1 or PEAN alone induced the necrotic syndrome, and double infection with WMV showed only limited increase of the rates.

Mixed viral infections are common in higher plants. These syndromes can involve members of the genus Potyvirus, which can induce severe synergistic symptoms when mixed infections occur in plant species such as soybean, cucumber, and tobacco $(1,11,12,18)$. Induction of synergistic syndromes has been reported in infection with potyviruses and unrelated viruses such as CMV $(10,16)$, Cauliflower mosaic virus (7), Potato virus $X$ (15), and Cowpea mosaic virus (1). Recently, it was suggested that such potyvirus-associated synergistic responses may be mediated by expression of potyviral 5'proximal sequences encoding P1 and the helper com- ponent protease (HC-Pro), and such a mechanism may enhance the pathogenicity and accumulation of CMV and Tobacco mosaic virus $(12,18)$. This synergism may be caused by suppression of host defense mechanisms by P1 and HC-Pro. Also, Brigneti et al. (2) have shown that HC-Pro of Potato virus $Y$ and the $2 \mathrm{~b}$ protein of CMV, required for long distance transport (3), are viral suppressors of host-plant defenses. In our study, too, a similar synergistic response may have occurred with double CMV and WMV infection of pea plants. Differences in virus movement and symptoms in pea plants induced by these CMV isolates may be responsible for variability of $2 b$ protein of CMV.

WMV is readily transmissible mechanically and transmissible in a nonpersistent manner by many aphid species, such as $M$. persicae and Aphis gossypii $(5,14)$. In western Japan, an infection cycle of WMV is formed between the garden pea, broad bean, and spinach as winter hosts, and cucurbits as summer hosts (20). In this situation, aphids are highly associated with virus transmission and spread. CMV also infects a wide range of food crops, ornamental plants, and weeds and is readily transmissible by 75 species of aphids (10). Because the CMVs isolated from pea plants in this study were not transmissible through seeds, diseased plants close to pea fields would be regarded as potential reservoirs of CMV infection. Under these conditions, WMV and CMV would be spread within the pea fields by aphids, and consequently, double infection with WMV and CMV could occur in the field. In the pea fields in the Wakayama prefecture, it appeared that necrotic diseases could be caused by either single infection with CMV alone or by double infection with CMV and WMV.

\section{ACKNOWLEDGMENTS}

We thank I. Fujisawa and F. Terami for providing the antisera to CYVV and ZYMV, and BYMV, respectively; and $\mathrm{T}$. Inouye for providing information on pea necrotic diseases.

\section{LITERATURE CITED}

1. Anjos, J. R., Jarlfors, U., and Ghabrial, S. A. 1992. Soybean mosaic potyvirus enhances the titer of two comoviruses in dually infected soybean plants. Phytopathology 82:10221027.

2. Brigneti, G., Voinnet, O., Li, W.-X., Ji, L.-H., Ding, S.-W., and Baulcombe, D. C. 1998. Viral pathogenicity determinants are suppressors of transgene silencing in Nicotiana benthamiana. EMBO J. 17:6739-6746.

3. Ding, S. W., Li, W.-X., and Symons, R. H. 1995. A novel naturally occurring hybrid gene encoded by a plant RNA virus facilitates long distance virus movement. EMBO J. 14:57625772.
4. Hanada, K., and Tochihara, H. 1980. Genetic analysis of cucumber mosaic, Peanut stunt and chrysanthemum mild mottle viruses. Ann. Phytopathol. Soc. Jpn. 46:159-168.

5. Inouye, T. 1964. A virus disease of pea caused by watermelon mosaic virus. Berichte des Ohara Instituts Bd 12, Ht. 2:133-143.

6. Inouye, T., Osaki, T., Yamazaki, S., and Shohara, K. 1975. An isolate of cucumber mosaic virus (CMV) causing severe necrosis of pea. (abstract in Japanese) Ann. Phytopathol. Soc. Jpn. 41:76.

7. Khan, M. A., and Demski, J. W. 1982. Identification of turnip mosaic and cauliflower mosaic viruses naturally infecting collards. Plant Dis. 66:253-256.

8. Matsumoto, T., Inoue, M., and Hasegawa, S. 1990. Cucumber mosaic virus causing mosaic symptoms and systemic necrosis on pea plants. (abstract in Japanese) Ann. Phytopathol. Soc. Jpn. 56:110.

9. Osaki, T., Ozaki, K., and Inouye, T. 1988. Some properties of pea stem necrosis virus isolated from pea in Japan. Ann. Phytopathol. Soc. Jpn. 54:210-216.

10. Palukaitis, P., Roossinck, M. J., Dietzgen, R. G., and Francki, R. I. B. 1992. Cucumber mosaic virus. Adv. Virus Res. 41:281-348.

11. Poolpol, P., and Inouye, T. 1986. Enhancement of cucumber mosaic virus multiplication by zucchini yellow mosaic virus in doubly infected cucumber plants. Ann. Phytopathol. Soc. Jpn. 52:22-30.

12. Pruss, G., Ge, X., Shi, X. M., Carrington, J. C., and Vance, V. B. 1997. Plant viral synergism: the potyviral genome encodes a broadrange pathogenicity enhancer that transactivates replication of heterologous viruses. Plant Cell 9:859-868.

13. Purcifull, D., Edwardson, J., Hiebert, E., and Gonsalves, D. 1984. Papaya ringspot virus. AAB Descriptions of Plant Viruses. No. 292.

14. Purcifull, D., and Hiebert, E. 1984. Watermelon mosaic virus 2. AAB Descriptions of Plant Viruses. No. 293.

15. Rochow, W. F., and Ross, A. F. 1955. Virus multiplication in plants doubly infected by potato viruses X and Y. Virology 1:10-27.

16. Takeshita, M., and Takanami, Y. 2000. Defective long-distance transport of Cucumber mosaic virus in radish is efficiently complemented by Turnip mosaic virus. J. Gen. Plant Pathol. 66:254-257.

17. Tochihara, H 1970. Some properties of chrysanthemum mild mottle virus and comparison of this virus with cucumber mosaic virus. Ann. Phytopathol. Soc. Jpn. 36:1-10

18. Vance, V. B., Berger, P. H., Carrington, J. C., Hunt, A. G., and Shi, X. M. 1995. 5'Proximal potyviral sequences mediate Potato virus $\mathrm{X} /$ potyviral synergistic disease in transgenic tobacco. Virology 206:583-590.

19. Wahyuni, W. S., Dietzgen, R. G., Hanada, K., and Francki, R. I. B. 1992. Serological and biological variation between and within subgroup I and II strains of cucumber mosaic virus. Plant Pathol. 41:282-297.

20. Yamamoto, T. 1986. Infection cycle of watermelon mosaic virus. Jpn. Agric. Res. Q. 19:259-265.

21. Zhang, L., Hanada, K., and Palukaitis, P. 1994. Mapping local and systemic symptom determinants of cucumber mosaic cucumovirus in tobacco. J. Gen. Virol. 75:31853191. 